\title{
Experimental Appraisal of Factors Involved in Provision of Donor Livers
}

\author{
J. H. PEACOCK,* M.D., CH.M., F.R.C.s. ; E. J. IMMELMAN, $\dagger$ M.B., F.R.C.S., F.C.S.(S.A.) \\ K. E. F. HOBBS, $\ddagger$ M.B., B.S., F.R.C.S.; S. K. MITRA, $\S$ M.A., M.S.; J. B. BOWES, $\|$ M.B., B.S., F.F.A. R.C.S.

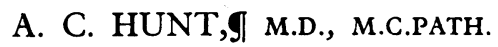

Brit. med. F., 1969, 1, 349-352

\begin{abstract}
ummary : The results of a series of porcine orthotopic $\checkmark$ liver homotransplants have shown that hepatic damage is related almost entirely to the period of warm ischaemia following death. Low flow perfusion with modified plasma would seem to be a satisfactory method of preserving cadaveric livers for at least six hours.
\end{abstract}

In man it would appear possible to use cadaver livers derived from patients who had or had not been treated with artificial ventilation during life, provided the period of warm ischaemia is not longer than 25 to 30 minutes.

\section{Introduction}

Liver transplantation in man inevitably requires the use of a cadaveric organ, which is required to support life immediately. The prolonged ischaemic interval to which the donor organ is subjected poses problems in organ preservation and storage far more critical than those encountered in renal transplantation.

Long-term survival after experimental liver transplantation for which living donors were used has been achieved by a sufficient number of investigators to suggest that it now constitutes a reasonable form of treatment for human liver disease. There are, however, few studies available in which cadaveric livers have been used (Marchioro et al., 1963 ; Fonkalsrud et al., 1967), and analysis of such studies, together with published clinical experience (Starzl et al., $1963 ; 1968 \mathrm{a}$ ), indicates that the hazards involved are far greater than those experienced under optimum research conditions with organs taken from living donor animals.

The essential problems vary according to whether or not the potential donor is already being maintained by artificial ventilation. Under such circumstances the time of transplantation is in the main predictable. In non-ventilated donors, however, timing is unpredictable and the recipient operation can only be started after the donor's death has been confirmed. These two categories of donor death pose different problems in organ preservation and storage which, from the point of view of providing a viable donor organ, can be looked at mainly in terms of probable differences in the periods of warm and cold ischaemia.

These differences are analysed in Table I. In the ventilator death it is only the period of warm ischaemia which differentiates it from an experimental transplant with the use of a living donor. In the non-ventilator deaths, however, not only is the critical period of warm ischaemia prolonged by at least a further 10 minutes but also the period of cold ischaemia is lengthened by a time equivalent to that required for the recipient operation to have reached the stage of hepatectomy. This might vary between one and three hours, depending on operability and the availability of anaesthetists and operating space. In this group, therefore, it becomes necessary to provide a

* Reader in Surgery.

t Lecturer in Surgery and Senior Registrar.

$¥$ Lecturer in Surgery.

Researoh Assistant.

Consultant Anaesthetist.

Reader in Forensic Pathology.

Reader in Forensic
University of Bristol. system of storage which will maintain liver viability for up to five hours. It appeared essential from these observations to analyse experimentally the effect on liver viability of the varying periods of warm and cold ischaemia that were likely to be encountered in clinical practice.

TABLB I.-Probable Time Factors in Hepatic Transplantation

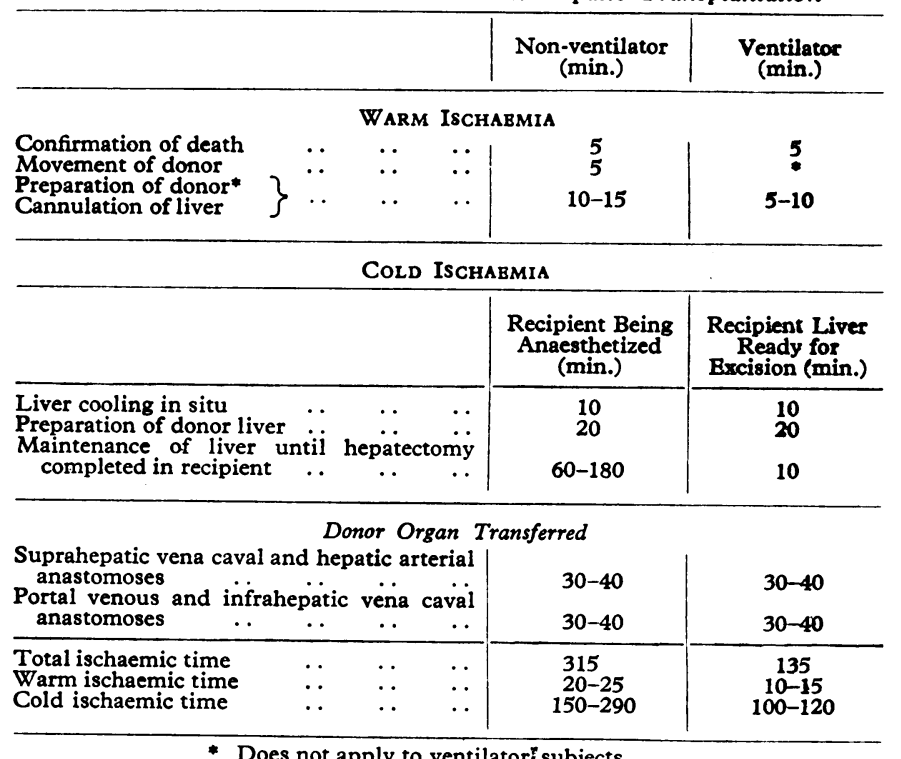

\section{Material and Methods}

Twenty-four allogeneic, orthotopic liver transplants were performed in pigs, the type of animal and basic recipient operative technique previously described being used (Peacock and Terblanche, 1967 ; Terblanche et al., 1968).

The recipient operation differed from that previously described in that portal blood was allowed to perfuse the liver after completion of the suprahepatic vena caval and portal anastomoses (Calne et al., 1968), a liver insulator was used to prevent intraoperative rewarming of the liver (Immelman et al., 1968), and in some animals a vagotomy with either pyloroplasty or gastroduodenostomy was introduced to prevent gastrooesophageal ulceration (Calne et al., 1968). In all cases grouped citrated blood was used for transfusion.

The donor animals were divided into five groups (Table II). In group 1 living donors were used and the animal's circulation was maintained until just before liver cannulation and cooling. In this group the liver was then placed on an extracorporeal pump perfusion system to assess this as a method of maintaining liver viability before transplantation.

In the other four groups cadaveric livers were used. Two methods of killing were employed: (a) slaughter by humane killer followed by exsanguination, the cadaver then being brought into the operating-theatre and the donor operation begun; and $(b)$ deep halothane anaesthesia on a ventilator followed by an intravenous dose of curare and heparin; ventila- 
tion was then discontinued, and no attempt was made to begin the donor operation until five minutes after ventricular fibrillation or standstill had occurred as determined by a continuous E.C.G. tracing.

\begin{tabular}{|c|c|c|c|}
\hline Group & Technique & $\begin{array}{c}\text { No. of } \\
\text { Experiments }\end{array}$ & $\begin{array}{c}\begin{array}{c}\text { Survivors } \\
\text { over } 24 \text { Hours }\end{array} \\
\end{array}$ \\
\hline $\begin{array}{l}1 \\
2\end{array}$ & \multirow{5}{*}{$\begin{array}{l}\text { Live donor, perfusion storage } \\
\text { Cadaver donor (humane killer and } \\
\text { bleeding), immediate transplant } \ldots \\
\text { Cadaver donor (ventilator death), } \\
\text { immediate transplant } \\
\text { Cadaver donor (humane killer and } \\
\text { bleeding), perfusion storage } \\
\text { Cadaver donor (ventilator death), } \\
\text { perfusion storage ... .. ... }\end{array}$} & 9 & 2 \\
\hline \multirow{4}{*}{$\begin{array}{l}3 \\
+\end{array}$} & & 5 & 3 \\
\hline & & 3 & 1 \\
\hline & & 1 & 1 \\
\hline & & 6 & 1 \\
\hline & Total $\quad \ldots \quad \ldots$ & 24 & 8 \\
\hline
\end{tabular}

In groups 2 and 3 the donor and recipient operations were started simultaneously, and a prolonged waiting period consequently ensued until the recipient operation had reached the stage of hepatectomy.

In groups 4 and 5 the cadaver livers were stored on a pump perfusion system, and the recipient operation was postponed to allow adequate assessment of this method of storage.

Liver Cooling and Perfusion Storage.-In all groups the liver temperature was lowered in situ by the portal infusion of 8 litres of a standard solution precooled to $4^{\circ} \mathrm{C}$. (Table III). The perfusate escaped through a cannula in the thoracic vena cava, the infrahepatic vena cava (and, in the living donor, the hepatic artery) being occluded at the time the infusion was started. In the cadaveric donors the portal infusion was usually started within five minutes of beginning the donor operation. In the perfusion storage groups the liver, after excision, was maintained on a perfusion system which had previously been developed in this laboratory (Hobbs et al., 1968). This consisted of perfusion at normal atmospheric pressure with a modified plasma solution (Table IV) at $6^{\circ} \mathrm{C}$. and a flow rate of $0.1 \mathrm{ml} . / \mathrm{g}$. of liver tissue $/$ minute. The $p \mathrm{H}$ of the perfusate was maintained at $7 \cdot 4$ by varying the $\mathrm{CO}_{2}$ inflow to the oxygenator. The duration of perfusion storage varied from 240 to 410 minutes (mean 300 minutes).

\section{TABLE III.-Liver Wash-through Fluid}

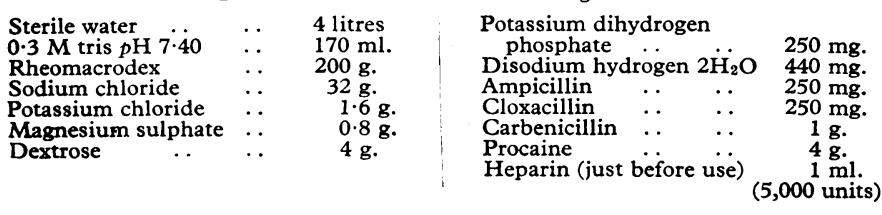

TABle IV.-Plasma for Liver Perfusion

$$
\text { To each litre of pig plasma is added: }
$$

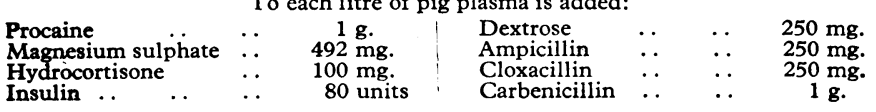

Postoperative Management.-Frequent blood samples for blood gas analysis, blood sugar, coagulation studies, and liver function tests were obtained from the recipient animal during intraoperative and postoperative periods. All animals received intramuscular and intravenous antibiotics. Intravenous fluids were given postoperatively for one or two days until the animal was able to take sufficient oral fluids. The volume of intravenous fluid required was judged by frequent haematocrit estimations and the urinary output. A complete necropsy was carried out as soon as possible after death in each case. The livers were examined with the naked eye, and areas of haemorrhage, necrosis, and infection were depicted in graphic form. In addition a block was taken from the worst and best areas of each of the four lobes for histological examination. Electron microscopy was undertaken if the period between death and necropsy was short.

\section{Results}

Sixteen animals died within 24 hours of the operation. Of these, one animal died during liver implantation as a result of a clotted portal bypass line; seven animals died shortly after completion of the recipient operation and eight died between 3 and 15 hours postoperatively. The causes of death are shown in Table $\mathrm{V}$.

$$
\begin{aligned}
& \text { TABLE V.-Cadaveric and Perfusion Stored Orthotopic Liver Homo- } \\
& \text { transplants. Causes of Death Under } 24 \text { Hours } \\
& \begin{array}{lllll}
\text { Technical } & \begin{array}{l}
\text { (Hepatic artery ligation (2) } \\
\text { inadequate portal bypass (2) }
\end{array} & \ldots & 4
\end{array}
\end{aligned}
$$

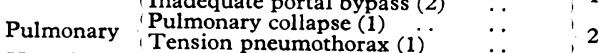

$$
\begin{aligned}
& \text { Hepatic outflowsion pneumothorax (1) } \\
& \text { Bleeding outfiow block } \\
& \begin{array}{l}
\text { Bleeding diathic } \\
\text { Idiopathich }
\end{array}
\end{aligned}
$$

Eight animals survived more than 24 hours; details of these are shown in Table VI, together with the warm and cold ischaemic intervals in each case. The gross morbidity of the livers in these animals is shown schematically in the accompanying figure, and compared with a series of 15 livers from a previous series of pig-liver transplants in which unstored organs taken from living donors (Hunt, 1967) were used. The histological features of the livers in the surviving animals were strictly comparable to the previous series quoted and showed only a mild mononuclear cell infiltration of the portal tracts and interlobular septa of those animals living longer than 48 hours. The only significant difference lay in the high incidence of cholangitis seen in the present series.

The serum levels of serum aspartate aminotransferase (S.G.O.T.) and serum alanine aminotransferase (S.G.P.T.)

\begin{tabular}{|c|c|c|c|c|c|c|c|c|c|c|c|}
\hline \multirow{2}{*}{ Donor } & \multirow{2}{*}{$\begin{array}{l}\text { Mode } \\
\text { of } \\
\text { Death }\end{array}$} & \multirow{2}{*}{ Technique } & \multicolumn{3}{|c|}{ Ischaemic Time (min.) } & \multirow{2}{*}{$\begin{array}{c}\text { Liver } \\
\text { Temperature } \\
\text { Before } \\
\text { Revascular- } \\
\text { ization } \\
\end{array}$} & \multirow{2}{*}{$\begin{array}{c}\text { Survival } \\
\text { Time } \\
\text { (Days) }\end{array}$} & \multirow{2}{*}{$\begin{array}{c}\text { Cholan- } \\
\text { gitis }\end{array}$} & \multirow{2}{*}{ Vagotomy } & \multirow{2}{*}{ Cause of Death } & \multirow{2}{*}{$\begin{array}{c}\text { Liver } \\
\text { Grade* }\end{array}$} \\
\hline & & & Total & Warm & Cold & & & & & & \\
\hline \multirow{6}{*}{ Cadaver } & \multirow{4}{*}{$\underset{\text { killer }}{\text { Humane }}$} & \multirow{2}{*}{$\begin{array}{c}\text { Perfusion } \\
\text { storage }\end{array}$} & 337 & 3 & 334 & - & $7 \cdot 5$ & - & $\begin{array}{l}\text { Not } \\
\text { attempted }\end{array}$ & \multirow{6}{*}{$\begin{array}{l}\text { Gastrointestinal track bleeding. } \\
\text { Oesophagogastric ulcer } \\
\text { Intestinal obstruction } \\
\text { Peritonitis, perforated stomal } \\
\text { ulcer, oesophagogastric ulcer } \\
\text { Gas gangrene of liver } \\
\text { Killed. Gastrostomy 3rd day for } \\
\text { gastric distension } \\
\text { Intraperitoneal haemorrhage } \\
\text { Virus pneumonia } \\
\begin{array}{l}\text { Biliary peritonitis and intestinal } \\
\text { obstruction }\end{array}\end{array}$} & A \\
\hline & & & $\begin{array}{l}370 \\
137\end{array}$ & $\begin{array}{r}5 \\
11\end{array}$ & $\begin{array}{l}365 \\
126\end{array}$ & $16 \cdot \overline{5^{\circ}} \mathrm{C}$. & $\begin{array}{l}4 \\
2\end{array}$ & $\begin{array}{l}+ \\
+\end{array}$ & $\begin{array}{l}\text { Complete } \\
\text { Incomplete }\end{array}$ & & B \\
\hline & & $\begin{array}{l}\text { Immediate } \\
\text { transplant }\end{array}$ & $\begin{array}{r}145 \\
98\end{array}$ & $\begin{array}{l}10 \\
13\end{array}$ & $\begin{array}{r}135 \\
85\end{array}$ & $\begin{array}{l}25^{\circ} \mathrm{C} . \\
12 \cdot 0^{\circ} \mathrm{C} .\end{array}$ & $\begin{array}{c}2 \\
12 \\
\text { (killed) }\end{array}$ & $\stackrel{+}{+}$ & $\begin{array}{l}\text { Complete } \\
\text { Complete }\end{array}$ & & $\stackrel{\mathrm{C}}{\mathrm{C}}$ \\
\hline & & $\begin{array}{l}\text { Perfusion } \\
\text { storage }\end{array}$ & 338 & 13 & 325 & $12 \cdot 0^{\circ} \mathrm{C}$ & 4 & - & Incomplete & & $\stackrel{\mathrm{A}}{\mathrm{B}}$ \\
\hline & \multirow{2}{*}{$\begin{array}{l}\text { Ventilator } \\
\text { death }\end{array}$} & $\begin{array}{c}\text { Immediate } \\
\text { transplant }\end{array}$ & 120 & 25 & 95 & $17 \cdot 9^{\circ} \mathrm{C}$. & $2 \cdot 5$ & - & Incomplete & & A \\
\hline & & $\begin{array}{l}\text { Perfusion } \\
\text { storage }\end{array}$ & 365 & 23 & 342 & $13 \cdot 2^{\circ} \mathrm{C}$ & 3.5 & + & $\begin{array}{l}\text { Not } \\
\text { attempted }\end{array}$ & & B \\
\hline
\end{tabular}
estimated 24 hours after transplant are shown in Table VII; these being compared with the 24-hour values of a series of 15 unstored hepatic transplants from living donors reported previously (Hunt, 1967). There is a significant difference in the * A Majority of liver normal on naked-eye examination. Most liver cells well preserved on histology. B= More extensive evidence of cell necrosis and/or haemorrhage
$\mathrm{C}=$ Majority of liver necrotic and/or haemorrhagic. 
values between this previous series and the groups in which cadaveric livers were used (S.G.O.T., P<0.01; S.G.P.T., $\mathrm{P}<0.05)$.
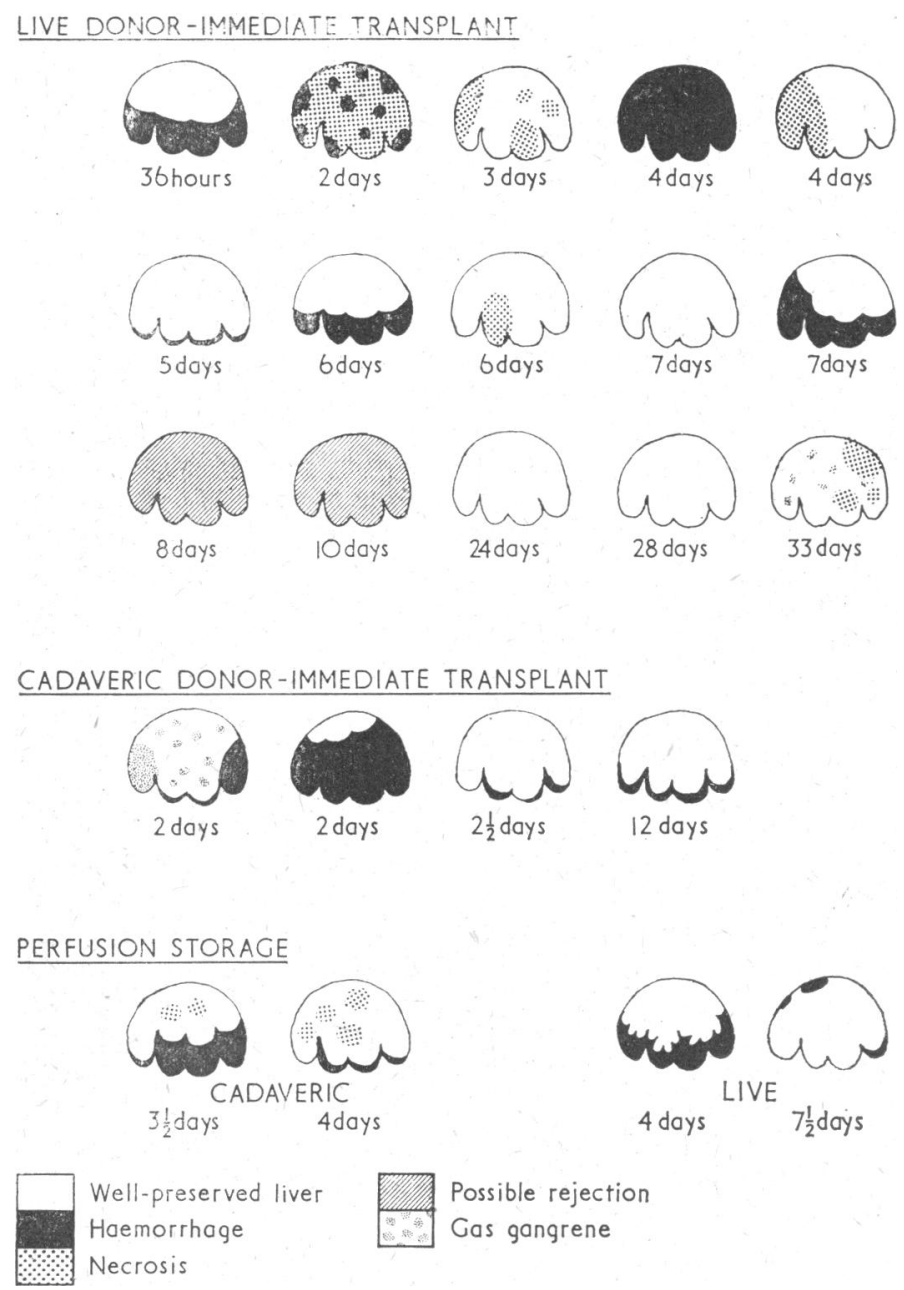

Possible rejection

Gas gangrene

Schematic representation of the gross morbidity of the liver in the eight surviving animals as compared with a previous series of 15 survivors where live donor organs were used followed by immediate transplantation.

TABLE VII.-Relationship of Type of Donor to Serum Levels of S.G.O.T. and S.G.P.T. 24 Hours After Transplantation

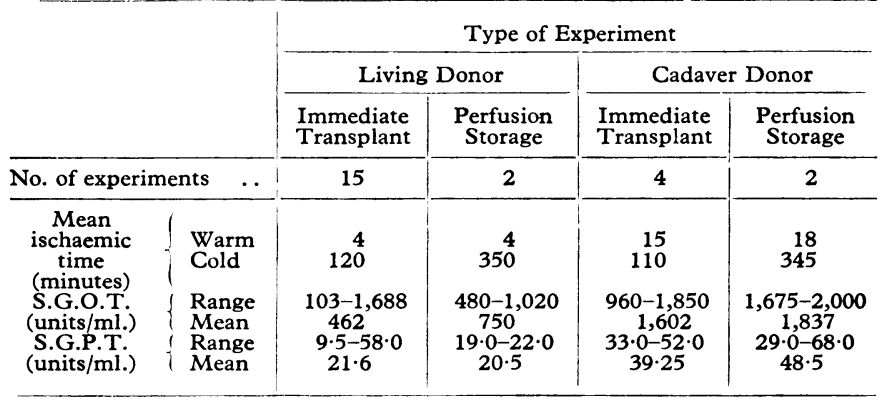

\section{Discussion}

The high mortality encountered in this study contrasts strikingly with the high rate of success seen where unstored livers are transplanted from live donors. Other studies in which cadaveric donor material was used confirm this high failure rate; Fonkalsrud et al. (1967), in a series of 24 canine orthotopic transplants, obtained only one survivor living beyond three days, 18 animals dying within 24 hours of a bleeding diathesis. Marchioro et al. (1963), in 10 experiments using cadaveric donor livers, obtained two survivors of more than three days, the majority succumbing to uncontrollable bleeding and severe hepatic damage as evidenced by sharp rises in the postoperative transaminase and bilirubin values.

There is no doubt that a major problem in the use of cadaveric livers is the inevitable period of warm ischaemia between the time of donor death and cold perfusion of the liver. Van Wyk et al. (1965) showed that if the liver is left in the cadaver for more than 30 minutes after death gross functional dissolution occurs. However, it is likely that far shorter periods of time are accompanied by varying degrees of hepatocellular damage. In the present series all efforts were made to mimic the conditions that would pertain in human practice. In animals sacrificed by humane killer a mean time of 11 minutes elapsed between death and cold perfusion of the liver. Where respiratory arrest was used as a method of sacrifice an even greater period of warm ischaemia was suffered by the liver. A mean time of 14 minutes elapsed between switching off the ventilator and the occurrence of ventricular standstill, followed by a further 11 minutes before the liver was cold-perfused-a total mean hypoxic time of 25 minutes.

The development of a severe and uncontrollable bleeding tendency accounted for the early death of the first six animals in group 1, despite the fact that live donors were used. In none of these animals was the condition reversible in spite of aggressive treatment with aminocaproic acid, Trasylol, protamine, or concentrated pig platelet transfusions. In an attempt to prevent this syndrome prophylactic aminocaproic acid was administered in doses of $0.1 \mathrm{~g} . / \mathrm{kg}$. body weight to all subsequent animals immediately before re-establishment of the portal circulation. Since the introduction of this regimen, and in contrast to the experience of other workers using cadaveric material, there have been no deaths as a result of coagulation defects. Serial clotting-times and thrombin clotting times with protamine correction are carried out postoperatively. Peaks of hypocoagulability were often seen up to 12 hours or more postoperatively in pigs receiving cadaveric livers, but in all cases were mild in degree and easily reversible with aminocaproic acid or protamine sulphate. Hypercoagulability with resultant thrombosis was not seen in any of the surviving animals.

The occurrence of hepatic outflow block, which has not previously been a problem in the pig, was responsible for three deaths in the immediate postoperative period. It is of interest to note that in all three cases the liver was obtained from cadavers in which respiratory arrest had been used as a method of sacrifice and probably reflected the long warm ischaemic time inherent in this procedure. Inadvertent ligation of the hepatic artery during excision of the donor liver from the cadaver was responsible for two deaths in the early part of the series, and was undoubtedly due to the technical difficulties inherent in isolating a small non-pulsatile artery. It is now our practice to confirm patency of the arterial segment by injecting a solution of methylene blue after excision of the donor liver and ensuring that all lobes of the liver perfuse evenly. This method also shows the presence of any leaks in the donor arterial segment.

In contrast to the relatively uncomplicated postoperative course of pigs receiving transplants from live donors, considerable metabolic problems were encountered in this series, reflecting the hepatocellular insult inherent in the use of cadaveric livers. The development of a severe metabolic acidosis and hypoglycaemia in the postoperative period required large quantities of sodium bicarbonate and dextrose for correction. In addition, a number of animals developed a syndrome of haemoconcentration as evidenced by a steeply rising haematocrit. The rapid transfusion of up to 6 litres of electrolyte solution was required in the first 12 hours to counteract this tendency. Starzl et al. (1968b) have noted a similar syndrome in dogs receiving damaged livers which they attribute to the development of a third fluid space. The cause of this 
would appear to be the rapid transudation of a lymph-like fluid from the surface of the transplanted liver into the peritoneal cavity. This is probably due either to a change in sinusoidal permeability or to the development of a degree of outflow block, and a number of animals had considerable quantities of only slightly blood-stained ascitic fluid at necropsy.

A number of animals in this series were subjecied to a vagotomy and drainage procedure in an attempt to prevent the previously observed hazard of gastro-oesophageal ulceration (Peacock and Terblanche, 1967). Whereas the performance of a complete vagotomy appears to effectively prevent this complication, the addition of this procedure has introduced a number of serious and unexpected additional complications. Massive gastric and intestinal distension occurs with great rapidity following complete vagotomy. This makes closure of the abdominal incision difficult and leads to diaphragmatic elevation and resultant pulmonary collapse. The two pulmonary deaths in this series resulted from this cause, the tension pneumothorax occurring from attempts to reinflate such a lung by forced positive-pressure ventilation. A previously undescribed risk of gastrointestinal distension is compression of the liver between the distended gut and the diaphragm. This has been observed in a number of vagotomized pigs and results in large areas of haemorrhagic necrosis of the liver, which becomes compressed into a thin sheet, especially towards the caudal ends of the lobes. In one animal this led to the rapid development of obvious clinical jaundice, which subsided dramatically when a gastrostomy was performed on the third postoperative day. Marked gastric atony and dilatation appears to persist after complete vagotomy in spite of adequate drainage procedures.

The incidence of cholangitis in this series has also been striking when compared with a previous series using the same biliary drainage system in which only one case of cholangitis was observed (Hunt, 1967). There would appear to be a distinct correlation between the incidence of cholangitis and the performance of a complete vagotomy. In only one of the five cases of cholangitis observed in this series was a vagotomy not performed, this animal dying as a result of intestinal obstruction which could be expected to result in ascending biliary infection. The pathogenesis of cholangitis in the vagotomized pig is probably due to a combination of gastroduodenal ileus and loss of the acid barrier in an animal whose feeding habits invite colonization.

Though many problems not previously encountered have led to a high mortality rate in this series, it is encouraging to note that the use of cadaveric livers and the system of organ storage described can produce livers capable of life-sustaining function if the initial ischaemic damage which results in the early coagulation and metabolic problems is overcome. This study has also stressed the need for a careful macroscopical and microscopical examination of the whole of the transplanted liver, as the scattered nature of the damaged areas renders fallacious any interpretation of the liver quality on the strength of a single biopsy alone. On this basis the pathological changes seen in the livers of the eight survivors have been no more extensive than those seen in the previous series where unstored livers from living donors were used.

Although this series is relatively small, the post-transplant serum enzyme levels have provided information which has been of value in assessing the relative importance of the warm and cold ischaemic intervals and the efficiency of the perfusion system used. In neither of the perfusion storage groups did a prolonged period of cold ischaemia lead to any significant increase in S.G.O.T. or S.G.P.T. concentrations, and it would be reasonable to assume that perfusion storage by this technique is therefore a satisfactory method of organ preservation. Increases in these enzymes arose purely from a prolongation of the warm ischaemic interval in the cadaveric group, and it is therefore this alone that is essentially critical. How long the warm ischaemic interval can be prolonged is as yet not precisely determined, but we believe that it is probably less than 30 minutes. What is hypothetical at the moment is that the function of an ischaemically damaged liver can be improved by a period of cold perfusion storage. There are some reasons for suggesting that this may occur, but accurate evidence is not available at the moment.

We gratefully acknowledge the continued help and encouragement of Professor A. G. Riddell in the preparation of this manuscript. We are further indebted to Mr. F. E. Badrick and the technical staff of the department of surgery and to Mr. D. B. Palmer for their help. This work has been carried out with the assistance of a United Bristol Hospitals Research grant.

\section{REPERENCES}

Calne, R. Y., Yoffa, D. E., White, H. J. O., and Maginn, R. R. (1968) Brit. F. Surg., 55, 203.

Fonkalsrud, E. W., Ono, H., Shafey, O. A., Joseph, W. L., Tocornal, J., and Longmire, W. P. (1967). Surgery, 62, 333

Hobbs, K. E. F., et al. (1968). Brit. F. Surg., 55, 696.

Hunt, A. C. (1967). In Colston Papers, vol. 19, “The Liver," edited by A. E. Read, p. 337 . London.

Immelman. E. J., Peacock, J. H., Hobbs, K. E. F., Mitra, S. K., Hunt, A. C.. and Bowes, J. B. (1968). Brit. med. f., 2, 220.

Marchioro, T. L., Huntley, R. T., Waddell, W. R., and Starzl, T. E. (1963). Surgery, 54, 900.

Peacock, J. H., and Terblanche, J. (1967). In Colston Papers, vol. 19, "The Liver," edited by A. E. Read, p. 333. London.

Starzl, T. E., Marchioro, T. L., von Kaulla, K. N., Hermann, G., Brittain, R. S., and Waddell, W. R. (1963). Surg. Gynec. Obstet., $117,659$.

Starzl, T. E., et al. (1968a). Surgery, 63, 549.

Starzl, T. E., Brettschneider, L., and Groth, C. G. (1968b). In Proceedings of the First International Congress of the Transplantation Society, Paris 1967, edited by J. Dausset, et al., p. 633. Copenhagen.

Terblanche, J., Peacock, J. H., Bowes, J., and Hobbs, K. E. F. (1968) f. surg. Res., 8, 151 .

van Wyk, J., Tait, I., and Eiseman, B. (1965). Surgery, 58, 374. 